\title{
Peran Komunitas Pijar dalam Enkulturasi Tradisi Pandai Besi kepada Generasi Muda
}

\author{
Meilda Amdza*, Kiki Zakiah \\ Fakultas Ilmu Komunikasi, Universitas Islam Bandung, Indonesia. \\ *meildaamdza98@gmail.com, kikizakiahdarmawan@gmail.com
}

\begin{abstract}
The tradition of blacksmith which is one of the richness of Indonesian culture, is now less noticed by the public, especially the younger generation. Therefore, it takes the process of inheritance through enculturation. The Pijar community is one of the groups that still preserves the tradition of blacksmiths. Activities in the Pijar community can be said to be unique because of the process of enculturation of blacksmiths with traditional patterns that have rarely been done. They often participate and hold an event with forging activities directly in public. The application is what makes researchers interested to discuss more deeply about enculturation in the Pijar community in bequeathing the tradition of blacksmiths. The purpose of this research is to find out the situations, events, and communicative actions in the Pijar community to bequeath the tradition of blacksmithing to the younger generation. This research uses qualitative method with communicative ethnographic approach. Data collection techniques used include interviews, observations, literature studies, and documentation. The subject of the study was the Pijar community with the key informant of a blacksmith as well as the founder of the community, Ibnu Pratomo. The object of the research is the application of enculturation of blacksmith traditions that exist in the community. Researchers apply source triangulation techniques (data) to test research. In addition, it will be equipped with live observations, and documentation in the form of official or personal notes, photos and images. As a result of the discussion of the data researchers get, the process of communication of the Pijar community can be said to be good, because it can achieve its goal to preserve the tradition of blacksmithing to the younger generation.
\end{abstract}

Keywords: Enculture, Communication, Community, Culture, Blacksmith.

Abstrak. Tradisi pandai besi yang merupakan salah satu kekayaan budaya Indonesia, kini kurang diperhatikan keberadaannya oleh masyarakat luas, khususnya generasi muda. Oleh karena itu, dibutuhkan proses pewarisan melalui enkulturasi. Komunitas Pijar merupakan salah satu kelompok yang sampai sekarang masih melestarikan tradisi pandai besi. Kegiatan dalam komunitas Pijar bisa dikatakan unik karena proses enkulturasi pandai besi dengan pola tradisional yang sudah jarang dilakukan. Mereka kerap kali mengikuti dan mengadakan sebuah event dengan kegiatan menempa secara langsung di depan masyarakat umum. Penerapan itulah yang membuat peneliti tertarik untuk membahas lebih dalam tentang enkulturasi di komunitas Pijar dalam mewariskan tradisi pandai besi. Tujuan dari penelitian ini yaitu untuk mengetahui situasi, peristiwa, dan tindak komunikatif dalam komunitas Pijar untuk mewariskan tradisi pandai besi kepada generasi muda. Penelitian ini menggunakan metode kualitatif dengan pendekatan etnografi komunikatif. Teknik pengumpulan data yang digunakan, meliputi wawancara, observasi, studi kepustakaan, dan dokumentasi. Subjek penelitian yang dipilih adalah komunitas Pijar dengan key informan seorang pandai besi sekaligus pendiri komunitas, Ibnu Pratomo. Objek penelitiannya yaitu penerapan enkulturasi tradisi pandai besi yang ada dalam komunitas tersebut. Peneliti menerapkan teknik triangulasi sumber (data) untuk menguji penelitian. Selain itu, akan dilengkapi dengan pengamatan langsung, dan dokumentasi berupa catatan resmi atau pribadi, foto dan gambar. Hasil pembahasan dari data peneliti dapatkan, proses komunikasi komunitas Pijar dapat dikatakan baik, karena bisa mencapai tujuannya untuk melestarikan tradisi pandai besi kepada generasi muda.

Kata Kunci: Enkulturasi, Komunikasi, Komunitas, Budaya, Pandai Besi. 


\section{A. Pendahuluan}

Dewasa ini, terdapat salah satu kekayaan budaya Indonesia tradisi pandai besi yang kini kurang diperhatikan keberadaannya. Keberagaman budaya yang melekat pada ciri khas bangsa Indonesia ini patut untuk dipertahankan kelestariannya. Oleh karena itu, hal tersebut perlu perhatian khusus agar tidak menghilang atau diklaim oleh negara lain. Selain itu, agar budaya asli tetap dilaksanakan oleh masyarakat, maka dibutuhkan proses pewarisan dengan belajar melalui budaya sendiri. Upaya tersebut juga dipertahankan oleh komunitas Pijar yang ada di daerah Antapani, Kota Bandung. Sampai sekarang, tradisi pandai besi yang ada dalam komunitasnya tetap dipelihara. Kegiatan pandai besi merupakan tradisi Indonesia yang tumbuh dan berkembang dalam jangka waktu yang lama. Setiap proses dan karya yang dihasilkan memiliki corak yang berbeda, dan memungkinkan untuk di modifikasi dalam karakteristik modern. Misalnya penggunaan bahan keris (pamor) yang dialihkan sebagai aksesoris berupa gelang dan cincin. Seperti jelas ahli sejarah Anthony Reid (Supriyanto, 2011), kekuasaan juga bisa diraih melalui kemahiran mengolah besi. Hal itu dikarenakan saat mengolah besi tidak cukup hanya memiliki keterampilan dalam pekerjaan kasar, tetapi batin pun harus diasah sampai halus agar besi itu tertempa sempurna.

Tidak banyak orang yang mengerti makna pada tradisi tersebut, maka dari itu komunitas Pijar berdiri sebagai ruang pembelajaran bagi masyarakat luas, khususnya generasi muda untuk mengulas sejarah, demi melestarikan tradisi menempa pusaka dari logam. Perjalanan tradisi pandai besi yang awalnya tidak banyak orang yang tahu, mulai disadari oleh generasi muda membuat beberapa pergeseran. Saat ini masyarakat dapat menemukan pandai besi sebagai alat pendidikan, ritual, dan komoditas berupa penjualan serta pertunjukkan seni.

Berdasarkan latar belakang yang telah diuraikan, penelitian ini berfokus pada peran komunitas Pijar dalam enkulturasi tradisi pandai besi kepada generasi muda. Selanjutnya, tujuan dalam penelitian ini diuraikan dalam pokok-pokok sbb.

1. Untuk mengetahui situasi komunikatif dalam komunitas Pijar untuk mewariskan tradisi pandai besi kepada generasi muda.

2. Untuk mengetahui peristiwa komunikatif dalam komunitas Pijar untuk mewariskan tradisi pandai besi kepada generasi muda.

3. Untuk mengetahui tindak komunikatif dalam komunitas Pijar untuk mewariskan tradisi pandai besi kepada generasi muda.

\section{B. Metodologi}

Penelitian ini menggunakan metode kualitatif dan etnografi komunikasi sebagai pendekatan untuk mengupas pola komunikasi dalam enkulturasi tradisi pandai besi di komunitas Pijar. Dell Hymes (dalam Kiki Zakiah, 2008) menegaskan batasan antara linguistik dan komunikasi dengan menyebut etnografi komunikasi bukan bagian dari kajian linguistik. Hymes pun mennyebutkan nested hierarchy (hierarki lingkar) unit-unit berupa situasi komunikatif adalah konteks terjadinya komunikasi, situasi bisa tidak berubah walaupun lokasinya berbeda, atau berubah dalam lokasi yang sama apabila aktivitas yang berbeda berlangsung di tempat tersebut pada saat yang berbeda. Situasi yang sama bisa mempertahankan konfigurasi umum yang konsisten pada aktivitas dan ekologi yang sama di dalam komunikasi yang berlangsung, meskipun ada perbedaan pada jenis interaksi tersebut.

Peristiwa komunikatif, yaitu unit dasar untuk tujuan deskriptif. Suatu peristiwa didefinisikan sebagai seluruh perangkat komponen yang utuh. Dell Hymes menyebutkan kerangka komponen tersebut sebagai nemonic.Komponen-komponen ini disingkat Hymes dengan kata SPEAKING, yang terdiri dari Setting, Participants, Ends, Act sequence, Keys, Instrumentalities, Norms of Interaction, dan Genre.

Tindak komunikatif, merupakan bagian dari peristiwa komunikatif yang umumnya bersifat koterminus dengan fungsi interaksi tunggal, seperti permohonan, pernyataan referensial, atau perintah. Bentuknya bisa dalam verbal maupun nonverbal.

Penelitian kali ini bertujuan untuk memperoleh informasi yang komprehensif serta akurat, oleh karena itu peneliti memerlukan teknik pengumpulan data. Peneliti menggunakan 
wawancara tidak terstruktur atau wawancara bebas. Peneliti berinteraksi secarara aktif dengan intuisinya pada saat memutuskan, merumuskan pernyataan dan melakukan pengamatan. Kemudian, peneliti memberikan kesempatan untuk informan menjelaskan pernyataan dan persepsinya, ia juga turut andil dalam menganalisa data. Peneliti pun mengamati dan merekam kegiatan yang diteliti melalui dokumentasi juga secara langsung di setiap kegiatan komunitas Pijar yang berhubungan dengan kegiatan belajar tentang tradisi pandai besi. Peneliti pun mencari data dan informasi dari beberapa situs internet dan arsip yang ada di komunitas Pijar.

\section{Hasil dan Pembahasan}

\section{Situasi Komunikatif dalam Enkulturasi Tradisi Pandai Besi di Komunitas Pijar}

Dell Hymes (Kiki Zakiah, 2008) menjelaskan bahwa situasi komunikatif merupakan konteks yang membuat komunikasi itu terjadi. Situasi itu bisa tidak berubah walaupun lokasinya berbeda, atau berubah dalam lokasi yang sama karena aktivitas yang dilakukannya berbeda. Selain belajar di bengkelnya, komunitas Pijar pun kerap beraktivitas pada lokasi yang berbeda, misalnya ketika menghadiri atau mengadakan sebuah acara. Meskipun lokasinya berbeda, situasi komunikatif kegiatan belajar dengan diskusi kelompok bersuasana kekeluargaan, sehingga memberikan kesempatan kepada anggotanya untuk bergurau dan santai.

Namun berbeda apabila kegiatan belajar praktik, suasananya akan terasa sakral karena dalam kegiatannya ketat akan hukum adat sehingga komunikator dan komunikan harus fokus serta mengikuti peraturan yang berlaku agar tidak terjadi kesalahan fatal. Situasi komunikatif juga mempengaruhi komunikasi yang terjadi, misalnya pada situasi kekeluargaan pada pengajar dan anggota yang saling memberikan pendapat dengan komunikasi verbal. Kedua situasi komunikatif di atas, kemudian akan mempengaruhi peristiwa komunikatif yang merupakan bagian dari situasi komunikatif.

\section{Peristiwa Komunikatif dalam Enkulturasi Tradisi Pandai Besi di Komunitas Pijar}

Berdasarkan data dalam temuan penelitian, komponen-komponen komunikasi yang saling berhubungan dalam peristiwa komunikatif pada enkulturasi pandai besi dalam komunitas Pijar, terdiri dari setting, participants, ends, act sequence, keys, instrumentalities, norm of interaction, dan genre. Keterpautan antar komponen-komponen dalam peristiwa komunikatif membentuk pola komunikasi dalam enkulturasi tradisi pandai besi di komunitas Pijar. Maka dari itu, dalam kegiatan belajar budaya di komunitas Pijar peneliti memetakan pola komunikasi dalam enkulturasi tradisi pandai besi di komunitas Pijar sebagai berikut:

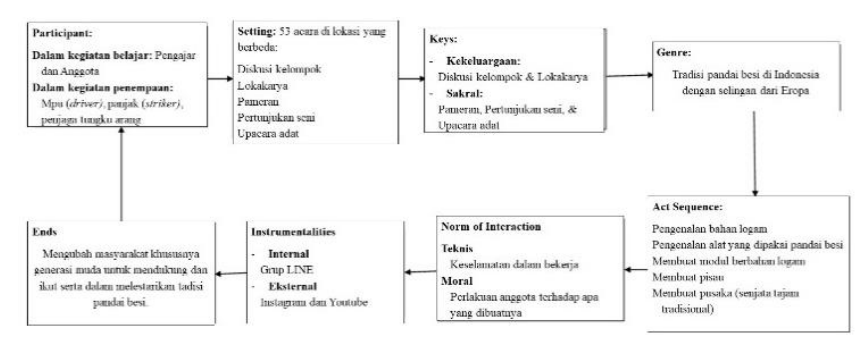

Gambar 1. Komunikasi Pijar

Berdasarkan temuan penelitian, komunitas Pijar sudah mengikuti atau membuat acara sebanyak 53 kali dengan lokasi yang berbeda. Di setiap kegiatan tersebut pengajar dan anggota bisa lebih dekat dengan masyarakat di luar komunitas, dimana terjadi interaksi tatap muka sehingga tradisi pandai besi dapat lebih diketahui di masyarakat luas khususnya generasi muda. Secara kegiatan belajar di komunitas Pijar orang yang terlibat dibagi menjadi dua, yaitu alumni ITB dan anggota senior sebagai pengajar serta anggota baru dan masyarakat umum sebagai siswa. Pada kegiatan secara tradisi pandai besi terdapat tiga partisipan yang terlibat, yaitu driver, panjak atau striker, dan orang yang menjaga agar tungku arang tetap menghasilkan panas. 
Kegiatan belajar yang dilakukan komunitas pijar tentunya memiliki tujuan, yaitu mengubah masyarakat khususnya generasi muda untuk mendukung dan ikut serta dalam melestarikan tadisi pandai besi. Pembawaan kekeluargaan yang dibangun komunitas Pijar, membuat proses komunikasi menjadi lebih interaktif. Pada dasarnya komunitas Pijar berkomunikasi melalui lisan dan tertulis saat menyampaikan materi secara tatap muka, namun ada juga media online berupa Youtube, Instagram juga grup LINE untuk bisa berkomunikasi dengan masyarakat umum khususnya generasi muda, maupun anggotanya melalui video, gambar atau tulisan. Secara teknis aturan yang berlaku di komunitas Pijar meliputi keselamatan dalam bekerja. Selain teknis, ada pun peraturan moral yang berlaku, yaitu tentang perlakuan anggota terhadap dirinya sendiri dan barang yang sudah dibuat, khususnya pada benda tajam. Dalam proses enkulturasi tradisi pandai besi, komunitas Pijar memberikan stimulus pada generasi muda secara langsung atau melalui media sosial, dengan mengenalkan tradisi pandai besi khas Indonesia. Saat kegiatan praktik, anggota baru akan menggunakan praktik pandai besi dengan budaya eropa untuk mempermudah mengenal alat-alat, dan teknik pandai besi yang standar.

\section{Tindak Komunikatif dalam Enkulturasi Tradisi Pandai Besi di Komunitas Pijar}

Tindak Komunikatif manjadi bagian dari peristiwa komunikatif yang pada dasarnya memiliki fungsi interaksi tunggal seperti permohonan, pernyataan referensial, atau perintah dengan bentuk verbal atau nonverbal. Dalam komunitas Pijar komunikasi berlangsung secara lisan atau menggunakan simbol. Dalam tahap penyampaian pesan, pengajar menggunakan komunikasi verbal baik dengan lisan, gambar dan tulisan. Hal tersebut berkaitan dengan situasi berkomunikasi, misalnya saat diskusi dan praktik lapangan atau upacara adat.

Tindak komunikatif yang ada dalam enkulturasi tradisi pandai besi di komunitas Pijar sangat beragam, maka peneliti memberi kesimpulan sebagai berikut:

Tabel 1. Bentuk Tindak Komunikatif

\begin{tabular}{|c|c|c|}
\hline $\begin{array}{c}\text { Jenis } \\
\text { Komunikasi }\end{array}$ & \multicolumn{2}{|c|}{ Bentuk Tindak Komunikatif } \\
\hline Verbal & \multicolumn{2}{|c|}{$\begin{array}{l}\text { 1. Setiap anggota menyatakan pendapat saat diskusi, kegiatan belajar, dan evaluasi } \\
\text { 2. Pengajar memberikan intruksi kepada anggota }\end{array}$} \\
\hline Non Verbal & $\begin{array}{l}\text { Saat Kegiatan Belajar Penempaan: } \\
\text { 1. Sketsa awal suatu yang akan ditempa } \\
\text { 2. Bakalan (billet) merupakan besi yang ditempa } \\
\text { 3. Pengajar menunjuk bakalan } \\
\text { 4. Pengajar memukul ke titk tertentu bersama pemula } \\
\text { 5. Anggota menutup sebelah matanya untuk mengukur } \\
\text { keseimbangan bilah. } \\
\text { 6. Warma besi yang dipanaskan sebagai indikator suhu } \\
\text { 7. Anggota menggunakan capit untulk membawa besi panas } \\
\text { 8. Anggota mengunakan sudut paron untuk membuat tang } \\
\text { 9. Suara gesekan kertas sebagai indikator ketajaman bilah } \\
\text { 10. Anggota merespon dengan senyuman }\end{array}$ & 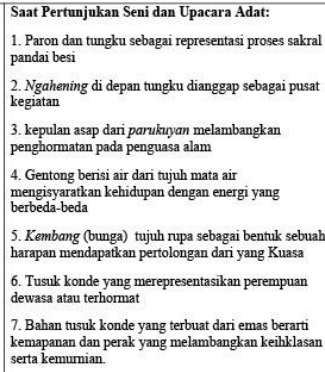 \\
\hline
\end{tabular}

Dari pembahasan hirarki lingkar sebelumnya, dapat disimpulkan model enkulturasi tradisi pandai besi dalam komunitas Pijar:

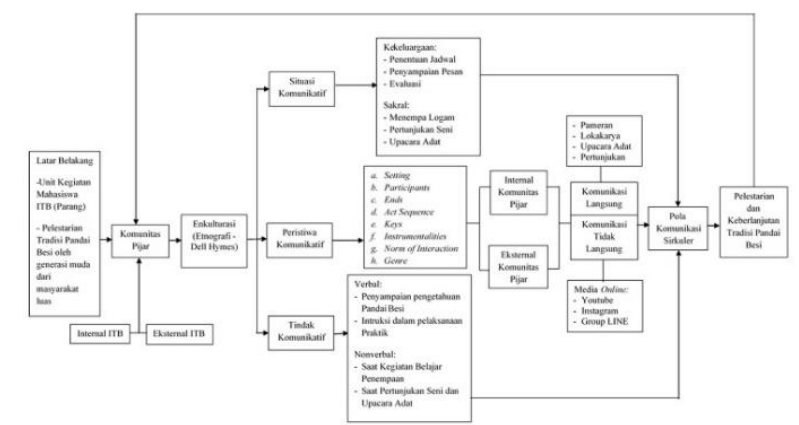

Sumber: Hasil Penelitian, 2021

Gambar 2. Komunitas Pijar 
Peneliti menyusun model enkulturasi tradisi pandai besi dalam komunitas Pijar berdasarkan temuan penelitian di lapangan dan hasil penelitian di pembahasan. Pada model enkulturasi tradisi pandai besi menjelaskan bahwa komunitas Pijar dibentuk karena dua latar belakang, yaitu berawal dari Unit Kegiatan Mahasiswa ITB (Parang) yang aktif membahas tentang tradisi pandai besi dan pelestarian tradisi pandai besi oleh generasi muda yang berasar dari masyarakat luas. Sehingga, pihak yang terlibat di komunitas Pijar berasal dari internal ITB yakni dosen, alumni serta mahasiswa, dan eksternal ITB yang merupakan generasi muda di luar lingkup ITB yang kemudian merasa tertarik dan memiliki dorongan untuk bergelut serta ikut andil dalam pelestarian tradisi pandai besi Indonesia di Komunitas Pijar.

Komunitas Pijar memiliki proses enkulturasi dimana peneliti membaginya menjadi tiga bagian dalam penelitian etnografi Dell Hymes, diantaranya yaitu situasi komunikatif, peristiwa komunikatif, dan tindak komunikatif. Situasi komunikatif yang terjadi dalam Komunitas Pijar terdapat dua situasi yang berbeda, yakni kekeluargaan yang cenderung bersifat santai dan sakral yang lebih serius karena berhadapan dengan praktik serta regulasi menempa.

Kemudian peristiwa komunikatif yang terjadi di Komunitas Pijar terdiri dari delapan komponen, yaitu sebanyak 53 kali kegiatan berada di lokasi yang berbeda dan disampaikan melalui kegiatan lokakarya praktik penempaan logsm, pertujukan seni, juga upacara adat (Setting). Pada peristiwa komunikatif enkulturasi di komunitas pijar terdiri dari dua partisipan (Participant) yaitu pengajar sebagai komunikator dan anggota atau masyarakat umum sebagai komunikan. Dalam proses komunikasi itu terdapat tujuan (Ends) untuk mengubah masyarakat agar mau mendukung dan ikut serta untuk melestarikan tradisi pandai besi melalui tahapan mengubah sikap, mengubah opini atau pendapat, mengubah perilaku juga dengan pembawaan (Keys) kekeluargaan dan sakral. Sehingga di dalam kegiatan tersebut terdapat aturan main (Norm of Interaction) teknis meliputi keselamatan dalam bekerja dan moral yaitu perlakuan anggota terhadap dirinya sendiri dan barang yang sudah dibuat agar digunakan hanya untuk hal baik. Hal ini dikarenakan kegiatannya menggunakan aliran (Genre) dengan nilai-nilai budaya Indonesia yang sarat akan hukum adat.

Terkait adanya peran komunikasi yang dilakukan internal komunitas dan luar komunitas, keduanya melakukan kegiatan berkomunikasi secara langsung maupun tidak langsung. Dalam komunikasi langsung, pihak internal komunitas dengan rutin bergiat beberapa acara mulai dari perkumpulan rutin, pameran, lokakarya, upacara adat, serta pertunjukan seni. Sedang komunikasi tidak langsung Komunitas Pijar merupakan pengetahuan pandai besi dan beberapa acara atau kegiatan yang kemudian dikomunikasikan melalui media online untuk menjangkau generasi muda lebih luas.

Proses enkulturasi bagian terakhir yaitu tindak komunikatif. Tindak komunikatif atau penyampaian isi pesan yang dilakukan di Komunitas Pijar disampaikan melalui komunikasi verbal dan nonverbal. Isi pesan yang dilakukan menggunakan komunikasi nonverbal dibagi menjadi dua, yaitu saat kegiatan belajar penempaan dan pertunjukan seni serta upacara adat. Dari ketiga proses enkulturasi tersebut akhirnya menjadi sebuah satu kesatuan yang utuh, yang kemudian dapat membentuk sebuah pola komunikasi sirkuler. Pola ini semakin memperjelas bahwa komunikasi yang dilakukan oleh Komunitas terdapat timbal balik atau feedback dan pengajar sebagai komunikator serta anggota sebagai komunikan memiliki kedudukan yang sama. Pola inilah yang akhirnya menjadi jalur sekaligus pembentuk Komunitas Pijar ikut andil dalam pelestarian serta keberlanjutan tradisi pandai besi Indonesia pada khalayak khususnya generasi muda.

\section{Kesimpulan}

Bedasarkan pola komunikasi dalam enkulturasi tradisi pandai besi di komunitas Pijar,terdapat beberapa kesimpulan, di antaranya:

1. Di setiap kegiatan enkulturasi dalam komunitas pastinya terdapat komunikasi yang berlangsung, seperti komunikasi kelompok yang ada di komunitas Pijar Komunikasi tersebut terdiri dari tahapan-tahapan, seperti menentukan jadwal pertemuan, penyampaian pesan, pelaksanaan kegiatan praktik, dan evaluasi. Selain belajar di 
sanggarnya, komunitas Pijar pun kerap beraktivitas pada lokasi yang berbeda, misalnya ketika menghadiri atau mengadakan sebuah acara. Meskipun lokasinya berbeda, situasi komunikatif kegiatan belajar dengan diskusi kelompok bersuasana kekeluargaan, sehingga memberikan kesempatan kepada anggotanya untuk bergurau dan santai. Namun berbeda apabila kegiatan yang berlangsung adalah belajar praktik, suasananya akan terasa sakral karena dalam kegiatannya ketat akan hukum adat sehingga komunikator dan komunikan harus fokus serta mengikuti peraturan yang berlaku agar tidak terjadi kesalahan fatal.

2. Berdasarkan hasil penelitian, komponen-komponen komunikasi yang saling berhubungan dalam peristiwa komunikatif pada enkulturasi pandai besi dalam komunitas Pijar, meliputi 53 lokasi yang berbeda dengan dua partisipan yaitu pengajar dan anggota atau masyarakat umum. Terdapat tujuan mengubah masyarakat agar mau mendukung dan ikut serta untuk melestarikan tradisi pandai besi melalui tahapan mengubah sikap, mengubah opini atau pendapat, mengubah perilaku juga dengan pembawaan kekeluargaan dan sakral. Sehingga terdapat batasan teknis dan moral, karena kegiatannya menggunakan aliran dengan nilai-nilai budaya Indonesia. Kemudian peristiwa ini berlangsung secara langsung, dan tidak langsung dengan media online sebagai alat pengirim pesannya. Keterpautan antar komponen-komponen dalam peristiwa komunikatif membentuk pola komunikasi dalam enkulturasi tradisi pandai besi di komunitas Pijar.

3. Tindak Komunikatif dalam komunitas Pijar berlangsung secara verbal maupun nonverbal. Misalnya berlangsung secara verbal ketika pengajar memberi instruksi kepada anggota. Ada juga pesan nonverbal menunjukan bagaimana pesan disampaikan melalui gerak tubuh, seperti ketika pengajar memberikan pernyataan materi tentang pembentukkan sebuah pamor, dan ketika kegiatan belajar di komunitas Pijar orang yang terlibat saat diskusi kerapkali tersenyum. Dalam kegiatan belajar komunitas Pijar mengandung berbagai simbol yang merupakan bentuk interaksi dan memiliki berbagai makna yang khas yaitu paron paron dan tungku sebagai simbol bahwa tradisi pandai besi merupakan proses sakral dalam melahirkan sesuatu yang mengandung kebaikan.

Situasi, peristiwa dan tindak komunikatif merupakan kesatuan dalam proses enkulturasi tradisi pandai besi di komunitas Pijar. Maka dari itu, enkulturasi yang dilakukan komunitas Pijar membentuk pola komunikasi sirkular karena dalam proses komunikasinya terdapat timbal balik atau feedback dan pengajar sebagai komunikator serta anggota atau masyarakat umum sebagai komunikan memiliki kedudukan yang sama.

\section{Acknowledge}

Peneliti menyadari bahwa dalam proses penelitian skripsi ini tidak luput dari peran orang-orang di sekitar peneliti yang telah memberikan masukan dan motivasi sehingga membantu peneliti dalam menyusun skripsi ini hingga selesai. Oleh karena itu, peneliti mengucapkan terima kasih banyak kepada seluruh pihak tersebut, khususnya komunitas Pijar yang telah memberikan izin dan membantu peneliti dalam penelitian ini.

\section{Daftar Pustaka}

[1] Djuarsa, Sasa S. 2003. Teori Komunikasi. Jakarta: Universitas Terbuka.

[2] Effendy, Onong Uchjana. 2000. Dinamika Komunikasi. Bandung: PT. Remaja Rosdakarya

[3] Mulyana, Deddy. 2015. Ilmu Komunikasi: Suatu Pengantar. Cetakan ke 19. Bandung: PT. Remaja Rosdakarya.

[4] Sandiah, Nasrun. 2017. "Model Komunikasi Antar-Teman Sejawat" dalam Journal Of Social anf Culture, Tahun 10 Nomor 20, Tahun 2017 (hlm. 106)

[5] Soekanto, S. 2007. Sosiologi Suatu Pengantar. Jakarta: Yayasan Penerbit Universitas Indonesia.

[6] Triyanto. (2015). Enkulturasi Perkeramikan pada Komunitas Perajin Desa Mayong Lor 
Jepara: Strategi Adaptasi dan Pemberlanjutan Potensi Kreatif Kebudayaan Lokal, IX, 112.

[7] Zakiah, Kiki. 2008. "Penelitian Etnografi Komunikasi: Tipe dan Metode" dalam Mediator: Jurnal Komunikasi. Universitas Islam Bandung. Volume 9, Nomor 1, Tahun 2008 (hlm. 186-188) 